
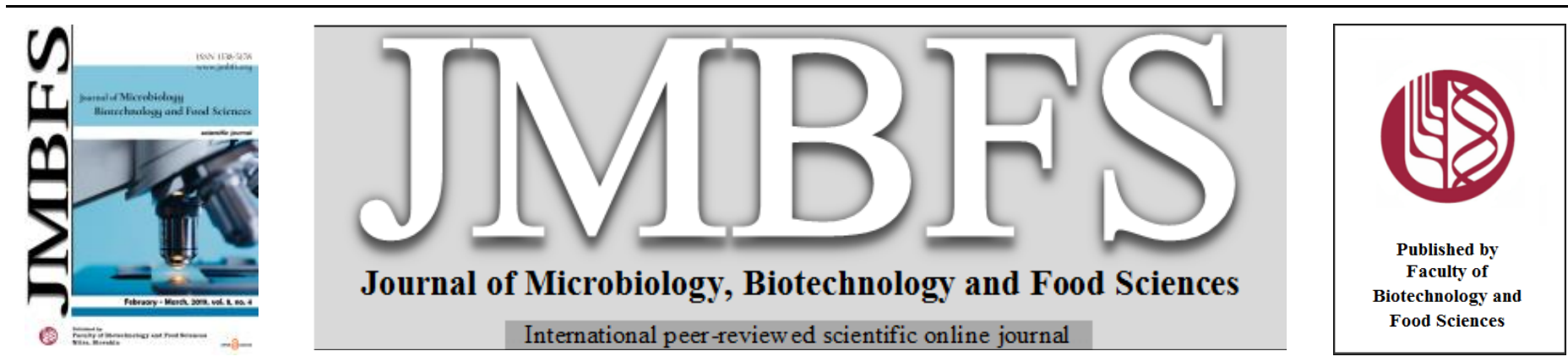

\title{
DETERMINATION OF ELEMENTS IN WILD EDIBLE MUSHROOMS: LEVELS AND RISK ASSESSMENT
}

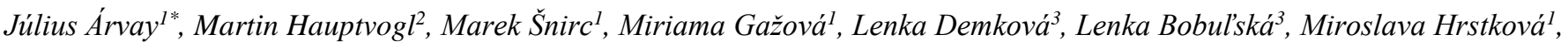 Daniel Bajčan ${ }^{1}$, L’uboš Harangozo ${ }^{1}$, Jana Bilč́ková ${ }^{4}$, Michal Miškeje ${ }^{4}$, Jana Štefánikovád, Vladimír Kunca ${ }^{5}$}

Address(es): Ing. Július Árvay, PhD.,

${ }^{1}$ Slovak University of Agriculture, Faculty of Biotechnology and Food Sciences, Department of Chemistry, Tr. A. Hlinku 2, 94976 Nitra, Slovakia.

${ }^{2}$ Slovak University of Agriculture, Faculty of European Studies and Regional Development, Department of Sustainable Development, Tr. A. Hlinku 2, 94976 Nitra, Slovakia.

${ }^{3}$ University of Prešov, Faculty of Humanities and Natural Sciences, Department of Ecology, 17. Novembra 1, 08116 Prešov, Slovakia.

${ }^{4}$ AgroBioTech - Research Center, Slovak University of Agriculture in Nitra, Tr. A. Hlinku 2, 94976 Nitra, Slovakia.

${ }^{5}$ Technical University in Zvolen, Faculty of Ecology and Environmental Sciences, Department of Applied Ecology, T.G. Masaryka

24, Zvolen, Slovakia.

*Corresponding author: julius.arvay@gmail.com

doi: 10.15414/jmbfs.2019.8.4.999-1004

ARTICLE INFO

Received 17. 7. 2018

Revised 25. 10. 2018

Accepted 25. 10. 2018

Published 1. 2. 2019

Regular article

OPEN OACCESS

\begin{abstract}
The paper is focused on monitoring of the content of selected elements ( $\mathrm{Al}, \mathrm{Cd}, \mathrm{Cu}, \mathrm{Hg}, \mathrm{Pb}, \mathrm{Se}$ and $\mathrm{Zn}$ ) in three species of edible mushrooms: Cantharellus cibarius Fr., Suillus luteus (L.) Roussel and Imleria badia (Fr.) Vizzini from three areas in Slovakia (Prašice, Bobrov and Dobroč). Qualitative and quantitative determination of the observed elements was performed by ICP-OES and/or CV-AAS. All results were statistically evaluated at both descriptive and differential analysis level. Due to the fact that picking and subsequent consumption of edible wild mushrooms is popular in Slovakia, the data obtained were evaluated and compared to tolerable weekly intakes defined by WHO. Based on the content of the monitored elements, PTWI values were not exceeded in any of the species from the studied sites. In some cases, however, specific content values, especially $\mathrm{Al}$, but also $\mathrm{Cd}$ and $\mathrm{Hg}$ were exceeded compared to the average concentrations of elements in mushrooms from uncontaminated areas. In general, it can be stated that regular and long-term
\end{abstract} consumption of the mushrooms does not pose any health risk to the consumers.

Keywords: Wild edible mushroom, Element, Risk assessment, Environment, Slovakia

\section{INTRODUCTION}

Edible wild growing mushrooms, as well as trace elements, are natura components of forest ecosystems. Particularly, wild growing mushrooms play an important role in the cycle of organic matter and trace element because they are able to degrade the organic substrate (saprophytic fungi) and/or coexist with the host organism (mycorrhizal fungi) and thus close the biological cycle in the forest ecosystem (Gupta et al., 2014; Petkovšek and Pokorny, 2013; Ouzouni et al., 2009). In combination with their characteristic high bioaccumulative capacity for risk elements (mainly saprophytic fungi) they reduce the content of xenobiotics in other environmental compartments (Árvay et al., 2017; Kojta et al., 2016; Stefanović et al., 2016; Angelovičová and Fazekašová 2014) at the expense of increasing content of the contaminants in their fructification organs (Slávik et al., 2013). Many studies show that the quality of the environment is a significant factor affecting the content of the risk elements in the above-ground parts of mushrooms, as well as plants and/or products (Falandysz 2017; Širić et al., 2017; Stanovič et al., 2016; Mleczek et al., 2015; Árvay et al., 2014; Slávik et al., 2014; Tomáš et al., 2014; Mleczek et al., 2013). Based on these properties, it can be stated that the wild growing mushrooms are an important bioindicator of environmental pollution (Záhorcová et al., 2016; Árvay et al., 2012), especially in areas affected by significant industrial activity (Gao and Chen, 2012).

Risk elements that are currently an important environmental problem (Alonso $\boldsymbol{e}$ al., 2000) get into the fructification organs of mushrooms through the mycelium (Širić et al., 2016; Rieder et al., 2011) while their translocation in the fructification organs is diverse (Zocher et al., 2018). Scientists assume that metals and/or metalloids are bound to the proteins in the hymenophore that has the highest enzyme activity. Saprophytic mushrooms have higher decomposition ability, as well as increased activity of catalase, which multipliesthe concentration of these elements (Alonso et al., 2000).

A long-term and regular consumption of wild edible mushrooms, especially from sites affected by anthropogenic contamination represents the highest health risk due to their high bioaccumulative capacity (Árvay et al., 2015; 2014). However, there are different culinary and/or conservation practices that can significantly reduce the content of risk elements in the mushrooms (Drewnowska et al., 2017; Falandysz and Drewnowska 2017).

The present paper focuses on the determination of the studied element content ( $\mathrm{Al}, \mathrm{Ag}, \mathrm{Cd}, \mathrm{Cu}, \mathrm{Hg}, \mathrm{Pb}, \mathrm{Se}$ and $\mathrm{Zn}$ ) in the above-ground parts of common edible wild growing mushroom species (Cantharellus cibarius Fr., Suillus luteus (L.) Roussel and Imleria badia (Fr.) Vizzini (known in the past as syn. Boletus badius (Fr.) Fr.) in three sites (Dobroč, Prašice and Bobrov) that represent areas with varying degrees of environmental burden of the studied elements. Based on the data on the content of the studied elements, we calculated the percentage of tolerable weekly intakes resulting from the regular and long-term consumption of mushrooms (Kalač, 2010) defined by the World Health Organization in the case of $\mathrm{Al}, \mathrm{Cd}, \mathrm{Hg}$ and $\mathrm{Pb}$. Such limits are not set for the other elements $(\mathrm{Cu}, \mathrm{Se}$ and $\mathrm{Zn})$.

\section{MATERIAL AND METHODS}

\section{Sample collection and preparation}

Samples of the wild edible mushrooms ( $\mathrm{n}=63$ ), were collected in three different sites (Dobroč, Prašice and Bobrov) in Slovakia (Fig. 1). Three mushroom species: $C$. cibarius $(\mathrm{n}=6+6+6)$, $S$. luteus $(\mathrm{n}=9+11+7)$ and I. badia $(\mathrm{n}=6+6+6)$ were collected in these sites in 2017. Each sampling point was defined by GPS coordinates. To meet the research objectives, the number of samples collected from each sampling point had to provide at least $100 \mathrm{~g}$ of the fresh mushroom samples ( $10 \mathrm{~g}$ of the dry weight). The collected mushrooms were cleaned of dirt with a ceramic knife and temporarily stored in PE sealable containers.

The mushroom samples were cleaned thoroughly in laboratory conditions and dried at the room temperature for about two weeks. Subsequently, the samples were dried at $45^{\circ} \mathrm{C}$ for 2 hours in a laboratory drier Venticell 111 (BMT, Czech Republic). After the drying, the samples were homogenized in a porcelain mortar and then the homogenized mushroom samples were stored in sealable PE bags. 


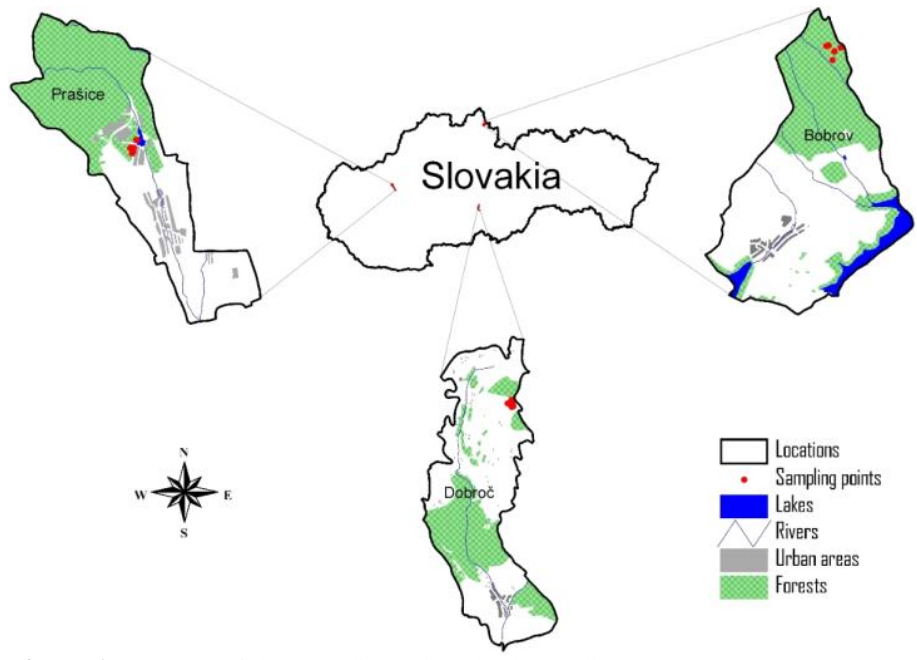

Figure 1 Location of the sampling points in the studied areas

\section{Mineralization}

Approximately $0.15-0.20 \mathrm{~g}$ was weighed from the prepared samples on analytica balances ABT-120/5DW (Kern \& Sohn, Germany) (accurate to 4 decimal places) and transferred to PTFE mineralization tubes. Mineralization was carried out by a pressure microwave digestion on EthosOne (Milestone, Italy) in $5 \mathrm{~mL}$ concentrated nitric acid (69\%) (Sigma Aldrich, Germany; trace purity) and $1 \mathrm{~mL}$ of $30 \%$ hydrogen peroxide (Sigma Aldrich, Germany; trace purity) with the addition of $2 \mathrm{~mL}$ of $\mathrm{ddH}_{2} \mathrm{O}\left(18.2 \mathrm{M} \Omega \mathrm{cm}^{-1} ; 25^{\circ} \mathrm{C}\right.$, Synergy UV, Merck Millipore, France). After the decomposition, the digestate was filtered through a quantitative filter paper Filtrak 390 (Munktell\&Filtrak, GmbH, Bärenstein, Germany) and filled with deionized water to $50 \mathrm{~mL}$.

\section{ICP-OES elemental analysis}

Elemental analysis was carried out on Agilent 720 ICP-OES spectrometer (Agilent Technologies Inc., Santa Clara, CA, USA) with axial plasma configuration and with auto-sampler SPS-3 (Agilent Technologies, Switzerland). Detailed experimental conditions were set as follows: RF power $1.45 \mathrm{~kW}$; plasma gas flow $16.0 \mathrm{~L} \mathrm{~min}^{-1}$; auxiliary gas flow $1.50 \mathrm{~L} \mathrm{~min}^{-1}$ and nebulizer gas flow $0.85 \mathrm{~L} \mathrm{~min}^{-1}$ and $\mathrm{CCD}$ detector temperature $-35^{\circ} \mathrm{C}$. Signal accusation time $3 \times 3 \mathrm{~s}$ for 3 replicates. All mushroom samples were analysed for concentration of 7 elements $\left(\mathrm{Al}, \mathrm{Cd}, \mathrm{Cu}, \mathrm{Pb}, \mathrm{Se}\right.$ and $\mathrm{Zn}$ ). ERM ${ }^{\circledR}-\mathrm{CE} 278 \mathrm{k}$ (Mussel tissue IRMM, Belgium) was used to check the measurement quality. Its recovery values (taking into account the water content) ranged from 85 to 123 $\%$ for most of the determined elements.

The total $\mathrm{Hg}$ content was determined by CV-AAS method on a selective $\mathrm{Hg}$ analyser AMA-254 (AlTec, Praque, Czech Republic) in dried and homogenized mushroom samples. The limit of detection for $\mathrm{Hg}$ was set at $1.5 \mathrm{ng} \mathrm{kg}^{-1}$ dry weight (DW) and the limit of quantification at $4.45 \mathrm{ng} \mathrm{kg}^{-1} \mathrm{DW}$ (Árvay et al., 2015)

\section{Statistical analysis}

All statistical analyses were performed in Statistica 9.0 (StatSoft Inc.). The obtained data on the concentration of the studied risk elements were processed a the level of descriptive statistics (minimum, maximum, mean, median and standard deviation). These data are shown in box plots. The statistical differences between individual species were evaluated using a non-parametric statistical Kruskal-Wallis test at the level of significance $\mathrm{p}<0.05$.

\section{Health risk assessment}

In order to assess the potential health risk from the consumption of the mushroom species from the studied sites, the obtained data on the concentration of $\mathrm{Al}, \mathrm{Cd}$, $\mathrm{Hg}$ and $\mathrm{Pb}$ were firstly calculated to fresh matter (Kalač, 2010). Subsequently, the percentage excess of tolerable weekly intakes per person weighing $70 \mathrm{~kg}$ for Al (140 mg person ${ }^{-1}$ week $\left.^{-1}\right), \mathrm{Cd}\left(0.44 \mathrm{mg}_{\text {person }}{ }^{-1}\right.$ week $\left.^{-1}\right), \mathrm{Hg}\left(0.28 \mathrm{mg}\right.$ person ${ }^{-1}$ week $\left.^{-1}\right)$ and $\mathrm{Pb}\left(1.75 \mathrm{mg}\right.$ person $^{-1}$ week $\left.^{-1}\right)$ (JECFA, 2012; JECFA, 2011), taking into account the average consumption of "Other vegetables and mushrooms" in Slovakia that was $0.19 \mathrm{~kg}$ person $^{-1}$ week $^{-1}$ in 2015 (Statistical Organization of Slovak Republic, 2016) were calculated according to the following formula.

$$
\% \mathrm{PTWI}=\frac{\text { element content }(\mathrm{FW}) \times 0.19}{P T W I_{\text {element }}} \times 100
$$

where: \%PTWI - percentage of the provisional tolerable weekly intake; element content $(F W)$ - content of the element in $\mathrm{mg} \mathrm{kg}^{-1}$ fresh weight; 0.19 - average mushroom consumption in Slovakia $\left(\mathrm{kg}^{-1}\right.$ person $^{-1}$ week $\left.^{-1}\right) ; P T W I_{\text {element }}-$ the value of provisional tolerable weekly intake for the studied element.

\section{RESULTS AND DISCUSSION}

In the present paper, we focused on monitoring of the content of selected elements in the above parts of three different species of edible mushrooms from three different areas in Slovakia (Prašice, Bobrov and Dobroč). These three locations are characterized by different environmental loads that were reflected in the contents of the monitored elements. All data are shown in Tables 1 to 3 and their mutual comparison in the Figure 2.

\begin{abstract}
Aluminium
Aluminium is one of the toxic elements, and its concentration in mushrooms can vary significantly. The results showed a wide range of $\mathrm{Al}$ concentration that depended on the site and a particular species of the edible wild-growing mushrooms. The highest average $\mathrm{Al}$ content was recorded in $C$. cibarius samples in the Prašice area. Despite the highest observed concentration of $\mathrm{Al}$ in a particular sample $\left(1888 \mathrm{mg} \mathrm{kg}^{-1} \mathrm{DW}\right)$ the average concentration was $394 \pm 753 \mathrm{mg}$ $\mathrm{kg}^{-1}$ DW, confirmed by the statistical analysis with significance level $\alpha=0.05$ (Table 4). The relatively high value of the standard deviation points to the non-parametric distribution of the $\mathrm{Al}$ concentration in the samples from the Prašice site, which is probably due to the local increase in the $\mathrm{Al}$ concentration In other areas, the $\mathrm{Al}$ content was as follows: Bobrov: $301 \pm 60.7 \mathrm{mg} \mathrm{kg}^{-1} \mathrm{DW}$ Dobroč: $161 \pm 22.9 \mathrm{mg} \mathrm{kg}^{-1} \mathrm{DW}$. In the case of $S$. luteus samples, the situation was different at the Prašice site. Here, the concentration of $\mathrm{Al}$ at the median level was significantly higher than in the samples of $C$. cibarius $\left(1042 \pm 694 \mathrm{mg} \mathrm{kg}^{-1} \mathrm{DW}\right.$ ) At the remaining two sites the $\mathrm{Al}$ content in $C$. cibarius was almost identical (Table 2). Table 3 shows Al contents in I. badia from the studied sites, where the Al contents were significantly lower, especially in Prašice $\left(93.7 \pm 210 \mathrm{mg} \mathrm{kg}^{-1}\right.$ DW) and Bobrov (20.9 $\left.\pm 34.5 \mathrm{mg} \mathrm{kg}^{-1} \mathrm{DW}\right)$. Almost identical contents of $\mathrm{Al}$ compared to the previous species were recorded in samples from Dobroc $\left(172 \pm 81.7 \mathrm{mg} \mathrm{kg}^{-1} \mathrm{SH}\right)$. The values of $\mathrm{Al}$ concentrations are in general higher than those obtained by Drewnowska and Falandysz (2015) and Kalač (2010), who reported the $\mathrm{Al}$ concentrations in samples of edible wild-type mushrooms at the level of $100-230$ and $150-370 \mathrm{mg} \mathrm{kg}^{-1} \mathrm{DW}$. It is probably due to a higher environmental load of $\mathrm{Al}$ (Falandysz et al., 2008).
\end{abstract}

\section{Cadmium}

Cadmium is one of the most toxic elements in the environment. It has a very high persistence and edible wild-growing mushrooms are characterized by its high bio accumulative capacity (Vollmann et al., 2015; Kalač and Svoboda, 2000). The content of $\mathrm{Cd}$ in the studied samples had a very wide range, probably due to environmental as well as species differences. The content of $\mathrm{Cd}$ in $C$. cibarius samples was $1.15 \pm 0.66 \mathrm{mg} \mathrm{kg}^{-1} \mathrm{DW}$ in the Prašice site, $0.62 \pm 0.09 \mathrm{mg} \mathrm{kg}^{-1} \mathrm{DW}$ in the Bobrov site and $0.28 \pm 0.18 \mathrm{mg} \mathrm{kg}^{-1} \mathrm{DW}$ in samples from the Dobroč site. The $\mathrm{Cd}$ content in samples of $S$. luteus was higher compared to the previous species. The Cd content was $0.85 \pm 0.50 \mathrm{mg} \mathrm{kg}^{-1} \mathrm{DW}$ in Prašice, $10.2 \pm 1.24 \mathrm{mg} \mathrm{kg}^{-1} \mathrm{DW}$ in Bobrov and $1.35 \pm 0.53 \mathrm{mg} \mathrm{kg}^{-1} \mathrm{DW}$ in Dobroč. In the case of $I$. badia samples, the Cd content was comparable to C. cibarius samples (Prašice: $3.88 \pm 2.01 \mathrm{mg} \mathrm{kg}$ ${ }^{1} \mathrm{DW}$, Bobrov: $2.91 \pm 1.78 \mathrm{mg} \mathrm{kg}{ }^{-1} \mathrm{DW}$, Dobroč: $1.61 \pm 1.91 \mathrm{mg} \mathrm{kg}^{-1} \mathrm{DW}$ ) Compared to the findings of other authors, the results, especially from the Bobrov site, differs significantly in $S$. luteus samples. Chudzyński and Falandysz (2008) reported an average Cd content of $5.90 \mathrm{mg} \mathrm{kg}^{-1} \mathrm{DW}$ in $S$. grevillea samples. Average values of the Cd content in Suillus spp. are below $1.00 \mathrm{mg} \mathrm{kg}^{-1}$ DW in uncontaminated areas (Szynkowska et al., 2008). Statistically significant differences in Cd content were found between sites Prašice-Bobrov and BobrovDobroč $(\alpha=0.05)$.

\section{Copper}

Copper belongs to the essential trace elements. The background concentration of $\mathrm{Cu}$ is $20-100 \mathrm{mg} \mathrm{kg}^{-1} \mathrm{DW}$ in edible wild-growing mushrooms. The average concentrations of $\mathrm{Cu}$ in our samples are in accordance to the findings of several authors (Alonso et al., 2003; Tüzen et al., 2007). No exceedance of $100 \mathrm{mg} \mathrm{kg}^{-1}$ DW was detected in any of the samples. The $\mathrm{Cu}$ content in C. cibarius samples differed in individual sites. The lowest concentrations were recorded in Prašice $\left(16.7 \pm 1.60 \mathrm{mg} \mathrm{kg}^{-1} \mathrm{DW}\right)$. The $\mathrm{Cu}$ concentration in the remaining two sites was more than two-fold (Bobrov: $48.7 \pm 3.86 \mathrm{mg} \mathrm{kg}^{-1} \mathrm{DW}$, Dobroč: $56.1 \pm 5.93 \mathrm{mg} \mathrm{kg}^{-1}$ DW). In the case of $\mathrm{Cu}$ concentration in S. luteus, the variability at the mean level was substantially more equal than in the previous species, however, the ranges of the measured values varied widely. The $\mathrm{Cu}$ content was at the following concentrations: Prašice: $27.8 \pm 13.2 \mathrm{mg} \mathrm{kg}^{-1} \mathrm{DW}$, Bobrov: $36.2 \pm 5.36 \mathrm{mg}$ $\mathrm{kg}^{-1}$ DW and Dobroč: $28.4 \pm 4.67 \mathrm{mg} \mathrm{kg}^{-1} \mathrm{DW}$. In the case of the last site, the situation was similar to that of $C$. cibarius, but the lowest values were measured in the Dobroč site, where the $\mathrm{Cu}$ concentrations were half the values of the first two sites (Table 3). The results obtained in the studied species are similar to those found by Alonso et al. (2003) and Tüzen et al., (2007), who recorded 25-75 mg 
$\mathrm{kg}^{-1} \mathrm{DW}$ of $\mathrm{Cu}$ in the samples of $C$. cibarius and $25-50 \mathrm{mg} \mathrm{kg}^{-1} \mathrm{DW}$ of $\mathrm{Cu}$ in $S$. granulatus, respectively.

\section{Mercury}

Mercury, like $\mathrm{Cd}$, is one of the most toxic elements. Its usual content in edible wild-growing mushrooms ranges from $0.50-10.0 \mathrm{mg} \mathrm{kg}^{-1} \mathrm{DW}$, depending on the species and/or locality (Kalač and Svoboda, 2000). The $\mathrm{Hg}$ content in all samples from the studied sites was in a relatively narrow interval. The $\mathrm{Hg}$ content in $C$. cibarius samples was as follows: Prašice: $0.99 \pm 1.93 \mathrm{mg} \mathrm{kg}^{-1} \mathrm{DW}$, Bobrov: $1.25 \pm 1.16 \mathrm{mg} \mathrm{kg}^{-1} \mathrm{DM}$ and Dobroč: $0.57 \pm 2.27 \mathrm{mg} \mathrm{kg}^{-1} \mathrm{DW}$; in samples of $S$ luteus: Prašice: $0.13 \pm 0.48 \mathrm{mg} \mathrm{kg}^{-1} \mathrm{DW}$, Bobrov: $0.58 \pm 2.27 \mathrm{mg} \mathrm{kg}^{-1} \mathrm{DW}$ and Dobroč: $0.14 \pm 2.61 \mathrm{mg} \mathrm{kg}^{-1} \mathrm{DW}$; in samples I. badia: Prašice: $0.42 \pm 0.36 \mathrm{mg} \mathrm{kg}^{-1}$ DW, Bobrov: $1.02 \pm 0.40 \mathrm{mg} \mathrm{kg}{ }^{-1} \mathrm{DW}$ and Dobroč $0.48 \pm 1.52 \mathrm{mg} \mathrm{kg}^{-1} \mathrm{DW}$. The results showed that $\mathrm{Hg}$ content was highest in all studied species in the Bobrov site, which was reflected by the highest measured concentrations in individual mushroom samples.

\section{Lead}

Generally, the lead content in edible wild-growing mushrooms from uncontaminated areas ranges from 1.00 to $10.0 \mathrm{mg} \mathrm{kg}^{-1}$ DW (Kalač and Svoboda, 2000). The average $\mathrm{Pb}$ content does not pose any health risk (Kalač, 2010). The $\mathrm{Pb}$ content in the $C$. cibarius samples ranged as follows: Prašice: $0.89 \pm 1.43 \mathrm{mg} \mathrm{kg}^{-1} \mathrm{DW}$, Bobrov: $0.66 \pm 0.36 \mathrm{mg} \mathrm{kg}^{-1} \mathrm{DW}$ and Dobroč: $0.21 \pm 0.31 \mathrm{mg} \mathrm{kg}^{-1} \mathrm{DW}$. In the case of $\mathrm{S}$. luteu it was as follows: Prašice: $0.34 \pm 0.35 \mathrm{mg} \mathrm{kg}^{-1} \mathrm{DW}$, Bobrov: $0.30 \pm 0.28 \mathrm{mg} \mathrm{kg}^{-1} \mathrm{DW}$ and Dobroč: $0.16 \pm 0.20$ $\mathrm{mg} \mathrm{kg}^{-1} \mathrm{DW}$. In the case of the last species I. badia, the situation was as follows: Prašice: $0.12 \pm 0.17 \mathrm{mg} \mathrm{kg}^{-1} \mathrm{DW}$, Bobrov: $0.07 \pm 0.14 \mathrm{mg} \mathrm{kg}^{-1} \mathrm{DW}$ and Dobroč $0.33 \pm 0.28 \mathrm{mg} \mathrm{kg}^{-1} \mathrm{DW}$. The results showed that the $\mathrm{Pb}$ content in the studied species from the monitored sites is in the lower part of the range reported by Kalač and Svoboda (2000). In some samples of $C$. cibarius from Prašice, the $\mathrm{Pb}$ concentration was higher as reported by García et al. (2009). However, the $\mathrm{Pb}$ content in S. luteus did not exceed values of $1.00-2.00 \mathrm{mg} \mathrm{kg}^{-1}$ DW reported by Rudawska and Leski (2005).

\section{Selenium}

Selenium belongs to elements with antioxidant properties (Ducsay et al., 2016) It also has an antagonistic effect on the toxic impacts of methylmercury
(Falandysz et al., 2003). The content of Se in mushrooms varies considerably among species, usually averaging at $2.00 \mathrm{mg} \mathrm{kg}^{-1} \mathrm{DW}$ (Kalač, 2010). C. cibarius belongs to species with the lowest bioaccumulative capacity for Se (Szynkowska et al., 2008), which was also shown by our results. The Se content in Prašice was $1.43 \pm 3.03 \mathrm{mg} \mathrm{kg}^{-1} \mathrm{DW}$, Bobrov: $1.35 \pm 0.34 \mathrm{mg} \mathrm{kg}^{-1} \mathrm{DW}$ and Dobroč: $1.01 \pm 0.86$ $\mathrm{mg} \mathrm{kg}^{-1} \mathrm{DW}$. The high variability of Se content in the samples of C. cibarius from Prašice were caused by a high concentration of this element in one sample (8.07 mg kg-1 DW). In the case of $S$. luteus, the Se content was as follows: Prašice: $0.70 \pm 1.07 \mathrm{mg} \mathrm{kg}^{-1} \mathrm{DW}$, Bobrov: $1.59 \pm 0.75 \mathrm{mg} \mathrm{kg}^{-1} \mathrm{DW}$ and Dobroč $5.24 \pm 1.98 \mathrm{mg} \mathrm{kg}^{-1} \mathrm{DW}$. The results shown a higher bioaccumulative capacity of $S$. luteus compared to the previous species. These findings were confirmed by Tüzen et al. (2007) who reported the Se content $S$. granulatus ranging from 5.00 to $10.0 \mathrm{mg} \mathrm{kg}^{-1} \mathrm{DW}$. The content of Se in I. badia was higher compared to the previous species. In the Prašice site, the Se content was $1.51 \pm 1.08 \mathrm{mg} \mathrm{kg}^{-1} \mathrm{DW}$, Bobrov: $2.21 \pm 1.32 \mathrm{mg} \mathrm{kg}^{-1}$ DW and Dobroč: $11.2 \pm 10.6 \mathrm{mg} \mathrm{kg}^{-1} \mathrm{DW}$. These values are significantly higher compared to the findings of Szynkowska et al. (2008), who reported the Se content in $X$. badius below $0.50 \mathrm{mg} \mathrm{kg}^{-1} \mathrm{DW}$, probably due to the increased local concentration of this element in the substrate. Statistically significant differences of Se content were found between PrašiceDobroč and Dobroč-Bobrov.

Zinc

Zinc is a micronutrient and therefore its content in edible wild-growing mushrooms is higher than previously evaluated elements. According to Kalač (2010), the average $\mathrm{Zn}$ content in mushrooms from uncontaminated areas ranges from 25.0 to $200 \mathrm{mg} \mathrm{kg}^{-1} \mathrm{DW}$. The $\mathrm{Zn}$ content can be significantly higher in mushrooms grown in the vicinity of zinc smelter (Colin-Hasen et al., 2002). In our samples, the average $\mathrm{Zn}$ content was in the standard range, however, in some samples from the Prašice site it was significantly higher. $\mathrm{Zn}$ content in $C$. cibarius samples from Prasice was $69.3 \pm 16.2 \mathrm{mg} \mathrm{kg}^{-1} \mathrm{DW}$, Bobrov: $73.5 \pm 5.17$ $\mathrm{mg} \mathrm{kg}{ }^{-1} \mathrm{SH}$ and Dobroč $94.0 \pm 6.35 \mathrm{mg} \mathrm{kg}^{-1} \mathrm{DW}$. In the case of $S$. luteus, the situation was different. In samples from Prašice, the content was $98.8 \pm 123 \mathrm{mg}$ $\mathrm{kg}^{-1}$ DW, Bobrov: $92.3 \pm 3.82 \mathrm{mg} \mathrm{kg}^{-1}$ DW and Dobroč: $95.1 \pm 12.4 \mathrm{mg} \mathrm{kg}^{-1} \mathrm{DW}$. The high standard deviation from the Prašice site was caused by a high content of $\mathrm{Zn}$ in one sample (452 mg kg-1 DW), which was probably caused by local contamination of the substrate. In the case of I. badia, the $\mathrm{Zn}$ content was $90.3 \pm 145 \mathrm{mg} \mathrm{kg}^{-1} \mathrm{DW}$ with maximum concentration of $411 \mathrm{mg} \mathrm{kg}^{-1} \mathrm{DW}$ in the Prašice site, $140 \pm 38.3 \mathrm{mg} \mathrm{kg}^{-1} \mathrm{DW}$ in Bobrov and $62.7 \pm 34.0 \mathrm{mg} \mathrm{kg}^{-1} \mathrm{DW}$ in Dobroč.

Table 1 Content of the studied elements in fruit bodies of $C$. cibarius Fr. $\left(\mathrm{mg} \mathrm{kg}^{-1} \mathrm{DW}\right)$

\begin{tabular}{|c|c|c|c|c|c|c|c|}
\hline & Al & Cd & $\mathbf{C u}$ & $\mathrm{Hg}$ & $\mathbf{P b}$ & Se & Zn \\
\hline & \multicolumn{7}{|c|}{$\mathrm{mg} \mathrm{kg}^{-1} \mathrm{DW}$} \\
\hline Prašice & $394 \pm 753$ & $1.15 \pm 0.66$ & $16.7 \pm 1.60$ & $0.99 \pm 1.93$ & $0.89 \pm 1.43$ & $1.43 \pm 3.03$ & $69.3 \pm 16.2$ \\
\hline$(n=6)$ & $292-1888$ & $1.08-2.55$ & $14.3-19.2$ & $0.77-5.75$ & $0.22-4.13$ & ND-8.07 & $49.7-86.7$ \\
\hline Bobrov & $301 \pm 60.7$ & $0.62 \pm 0.09$ & $48.7 \pm 3.86$ & $1.25 \pm 1.16$ & $0.66 \pm 0.36$ & $1.35 \pm 0.34$ & $73.5 \pm 5.17$ \\
\hline$(n=6)$ & $259-410$ & $0.51-0.76$ & $41.3-53.0$ & $0.07-3.34$ & ND-1.10 & $0.75-1.56$ & $66.7-80.6$ \\
\hline Dobroč & $161 \pm 22.9$ & $0.28 \pm 0.18$ & $56.1 \pm 5.93$ & $0.57 \pm 2.27$ & $0.21 \pm 0.31$ & $1.01 \pm 0.86$ & $94.0 \pm 6.35$ \\
\hline$(n=6)$ & $123-187$ & $0.04-0.51$ & $48.2-66.0$ & $0.14-5.93$ & ND-0.85 & $0.39-2.54$ & $92.8-108$ \\
\hline
\end{tabular}

Table 2 Content of the studied elements in fruit bodies of $S$. luteus (L.) Roussel (mg kg-1 DW)

\begin{tabular}{lccccccc} 
& $\mathbf{A l}$ & $\mathbf{C d}$ & $\mathbf{C u}$ & $\mathbf{H g}$ & $\mathbf{P b}$ & Se & Zn \\
\cline { 2 - 8 } & & & & $\mathrm{mg} \mathrm{kg}^{-1} \mathrm{DW}$ & & & \\
\hline Prašice & $1042 \pm 694$ & $0.85 \pm 0.50$ & $27.8 \pm 13.2$ & $0.13 \pm 0.48$ & $0.34 \pm 0.35$ & $0.70 \pm 1.07$ & $98.8 \pm 123$ \\
$(\mathrm{n}=11)$ & $217-2246$ & $0.50-2.16$ & $23.0-70.0$ & $0.05-1.29$ & $\mathrm{ND}-0.86$ & $\mathrm{ND}-3.74$ & $61.4-452$ \\
\hline Bobrov & $315 \pm 388$ & $10.2 \pm 1.24$ & $36.2 \pm 5.36$ & $0.58 \pm 2.27$ & $0.30 \pm 0.28$ & $1.59 \pm 0.75$ & $92.3 \pm 3.82$ \\
$(\mathrm{n}=7)$ & $157-1083$ & $7.93-11.0$ & $26.8-39.8$ & $0.03-5.74$ & $\mathrm{ND}-0.79$ & $0.10-1.89$ & $84.0-95.6$ \\
\hline Dobroč & $175 \pm 63.5$ & $1.35 \pm 0.53$ & $28.4 \pm 4.67$ & $0.14 \pm 2.61$ & $0.16 \pm 0.20$ & $5.24 \pm 1.98$ & $95.1 \pm 12.4$ \\
$(\mathrm{n}=9)$ & $142-301$ & $0.53-1.98$ & $24.4-38.8$ & $0.05-8.06$ & $\mathrm{ND}-0.49$ & $2.36-9.31$ & $78.2-118$ \\
\hline
\end{tabular}

ND: not detected

Table 3 Content of the studied elements in fruit bodies of I. badia (Fr.) Vizzini (mg kg-1 DW)

\begin{tabular}{lccccccc} 
& $\mathbf{A l}$ & $\mathbf{C d}$ & $\mathbf{C u}$ & $\mathbf{H g}$ & $\mathbf{P b}$ & $\mathbf{S e}$ & $\mathbf{Z n}$ \\
\cline { 2 - 8 } & & & & $\mathrm{mg} \mathrm{kg}^{-1} \mathrm{DW}$ & & & \\
\hline Prašice & $93.7 \pm 210$ & $3.88 \pm 2.01$ & $42.0 \pm 6.20$ & $0.42 \pm 0.36$ & $0.12 \pm 0.17$ & $1.51 \pm 1.08$ & $90.3 \pm 145$ \\
$(\mathrm{n}=6)$ & $51.6-558$ & $1.63-6.77$ & $34.8-50.5$ & $0.09-1.11$ & $\mathrm{ND}-0.37$ & $\mathrm{ND}-2.65$ & $79.4-411$ \\
\hline Bobrov & $20.9 \pm 34.5$ & $2.91 \pm 1.87$ & $43.8 \pm 13.5$ & $1.02 \pm 0.40$ & $0.07 \pm 0.14$ & $2.21 \pm 1.32$ & $140 \pm 38.3$ \\
$(\mathrm{n}=6)$ & $13.5-103$ & $0.36-5.04$ & $14.5-51.3$ & $0.82-1.90$ & $\mathrm{ND}-0.36$ & $\mathrm{ND}-3.03$ & $61.3-174$ \\
\hline Dobroč & $172 \pm 81.7$ & $1.61 \pm 1.91$ & $21.4 \pm 7.30$ & $0.48 \pm 1.52$ & $0.33 \pm 0.28$ & $11.2 \pm 10.6$ & $62.7 \pm 34.0$ \\
$(\mathrm{n}=6)$ & $110-352$ & $\mathrm{ND}-4.93$ & $17.4-36.8$ & $0.22-4.15$ & $0.03-0.81$ & $2.93-28.9$ & $37.9-122$ \\
\hline
\end{tabular}

ND: not detected 
Cantharellus cibarius
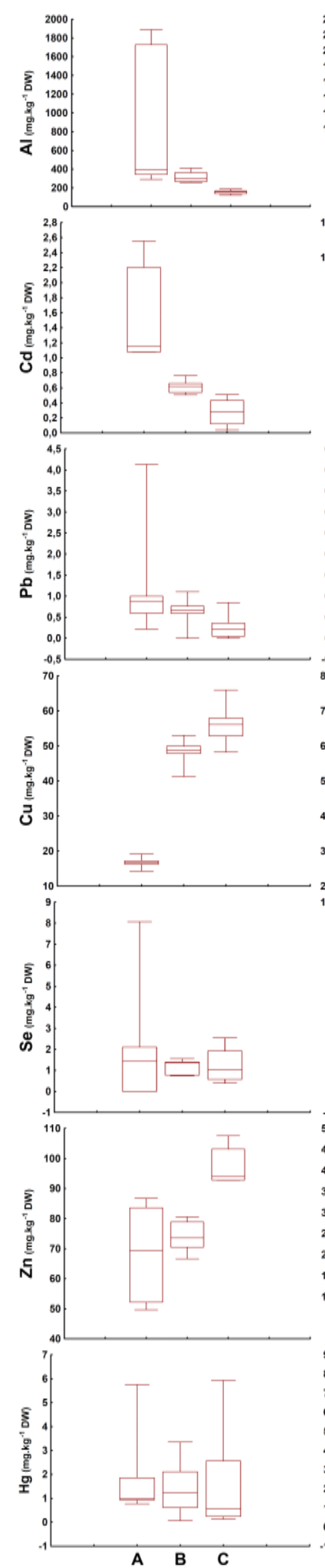

Suillus luteus
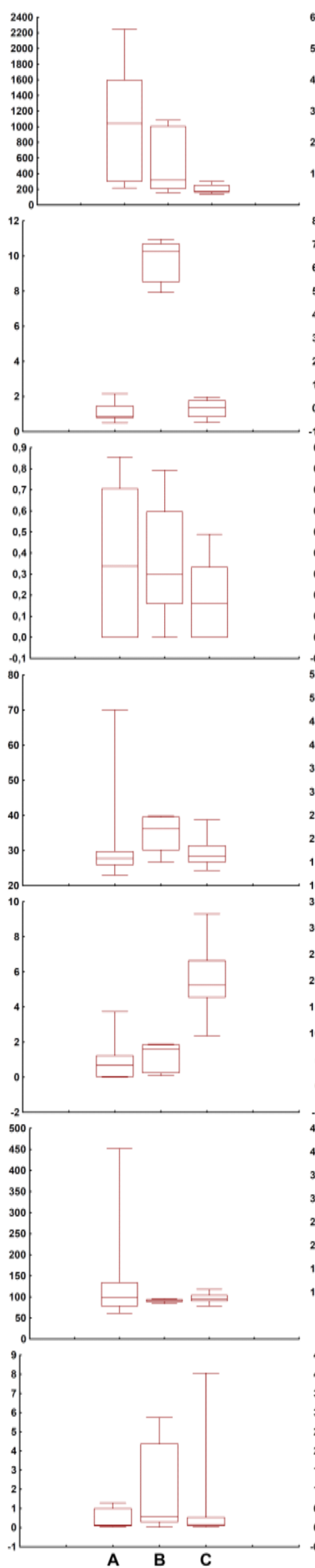

Imleria badia
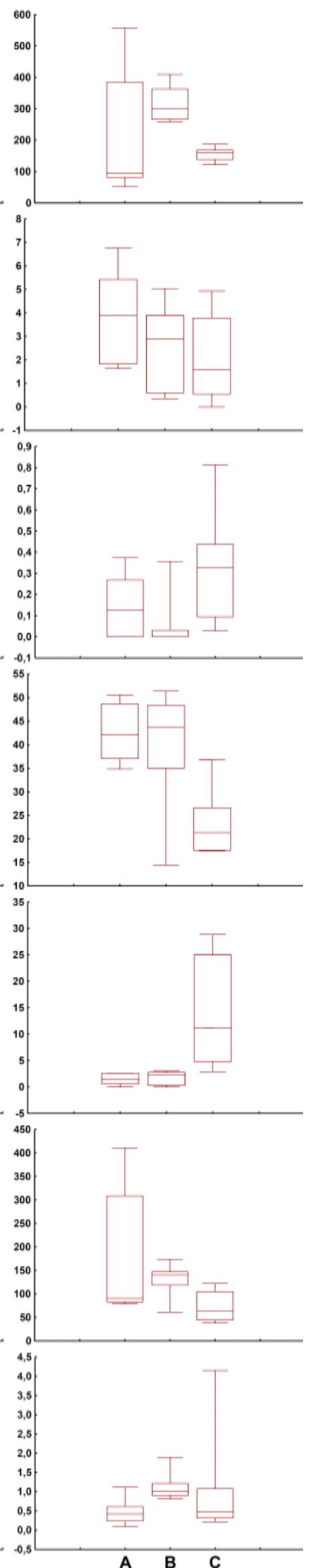

Figure 1 Comparison of the element contents in the studied mushroom species in the three sites 
Table 4 P-values showing statistical significance of the studied element differences between individual sites

\begin{tabular}{|c|c|c|c|}
\hline & & Prašice & Dobroč \\
\hline Dobroč & \multirow{2}{*}{ Al } & $0.0027^{*}$ & \\
\hline Bobrov & & 0.1515 & 0.1528 \\
\hline Dobroč & \multirow{2}{*}{ Cd } & 0.6088 & \\
\hline Bobrov & & $0.0014^{*}$ & $0.0025^{*}$ \\
\hline Dobroč & \multirow{2}{*}{$\mathrm{Cu}$} & 0.8743 & \\
\hline Bobrov & & 0.0842 & 0.1528 \\
\hline Dobroč & \multirow{2}{*}{ Hg } & 0.9929 & \\
\hline Bobrov & & 0.3389 & 0.5070 \\
\hline Dobroč & \multirow{2}{*}{$\mathbf{P b}$} & 0.8048 & \\
\hline Bobrov & & 0.9953 & 0.7358 \\
\hline Dobroč & \multirow{2}{*}{$\mathrm{Se}$} & $0.0007^{*}$ & \\
\hline Bobrov & & 0.3389 & $0.0025^{*}$ \\
\hline Dobroč & \multirow{2}{*}{ Zn } & 0.9803 & \\
\hline Bobrov & & 0.8722 & 0.4429 \\
\hline
\end{tabular}

*: statistically significant differences at the level of significance $\alpha=0.05$

\section{Risk assessment}

Consumption of common edible wild mushrooms is a tradition in Slovakia and therefore we consider it necessary to assess a potential health risk resulting from a regular and long-term consumption of mushrooms. Provisional tolerable weekly intake (PTWI) was evaluated in each species. PTWI is defined by the WHO for $\mathrm{Al}, \mathrm{Cd}, \mathrm{Hg}$ and $\mathrm{Pb}$. The theoretical health risk resulting from consumption of the studied species was estimated for a person weighing $70 \mathrm{~kg}$ that consumes according to the Statistical Office of the Slovak Republic (2016) per year $0.19 \mathrm{~kg}$ of "other vegetables and mushrooms" per week.

The calculated percentage values of the tolerable intake for the studied elements are shown in Table 5. The results showed that the PTWI values were not exceeded in any of the species. The highest value was recorded in S. luteus from the Bobrov site, however, it was still well below the limit value. In general, it can be stated that from the site point of view the risk was as follows: Bobrov $>$ Prašice $>$ Dobroč.

In terms of PTWI for the studied elements it was as follows: $\mathrm{Cd}>\mathrm{Hg}>\mathrm{Al}>\mathrm{Pb}$. The international legislation does not define health risk limits for $\mathrm{Cu}$, Se and $\mathrm{Zn}$.

Table 5 Percentage of the Provisional tolerable weekly intake values (mg person ${ }^{1}$ week $^{-1}$ ) in the studied mushroom species

\begin{tabular}{|c|c|c|c|c|}
\hline & & Prašice & Bobrov & Dobroč \\
\hline \multirow{3}{*}{$\begin{array}{l}\text { Al } \\
(140)\end{array}$} & C. cibarius & 5.35 & 4.09 & 2.19 \\
\hline & S. luteus & 14.1 & 4.28 & 2.38 \\
\hline & I. badia & 1.27 & 0.28 & 2.33 \\
\hline \multirow{3}{*}{$\begin{array}{l}\text { Cd } \\
(0.44)\end{array}$} & C. cibarius & 4.97 & 2.68 & 1.21 \\
\hline & S. luteus & 3.67 & 44.0 & 5.83 \\
\hline & I. badia & 16.8 & 12.6 & 6.95 \\
\hline \multirow{3}{*}{$\begin{array}{l}\text { Hg } \\
(0.28)\end{array}$} & C. cibarius & 6.72 & 8.48 & 3.87 \\
\hline & S. luteus & 0.88 & 3.94 & 1.02 \\
\hline & I. badia & 2.85 & 6.92 & 3.26 \\
\hline \multirow{3}{*}{$\begin{array}{l}\mathrm{Pb} \\
(1.75)\end{array}$} & C. cibarius & 0.97 & 0.72 & 0.23 \\
\hline & S. luteus & 0.37 & 0.33 & 0.17 \\
\hline & I. badia & 0.13 & 0.08 & 0.36 \\
\hline
\end{tabular}

\section{CONCLUSION}

The paper focused on monitoring of the contamination level of three species of edible wild-growing mushrooms: $C$. cibarius, $S$. luteus and I. badia from Prašice, Bobrov and Dobroč sites with risk elements (Al, Cd, $\mathrm{Cu}, \mathrm{Hg}, \mathrm{Pb}, \mathrm{Se}$ and $\mathrm{Zn}$ ). Aluminium exceeded values published in the literature in some cases, especially at the Prašice site. Based on the PTWI results, the concentrations

mercury

and cadmium were relatively high in some cases. The concentration of lead did not exceed the limit values in any location. The concentration of the studied risk elements did not exceed the WHO limit values in any of the cases. Consumption of mushrooms from the Bobrov site might pose a potential risk in terms of $\mathrm{Cd}$ content. However, in general, it can be concluded that the consumption of the studied mushroom species from all sites does not present any health risk arising from their regular consumption.
Acknowledgements: This work was supported by the project VEGA 1/0591/18 (80\%) and AgroBioTech Research Centre built in accordance with the project "Building, AgroBioTech" Research Centre ITMS $26220220180(20 \%)$.

\section{REFERENCES}

Alonso, J., Garcia, M.A., Péréz-López, M. \& Melgar, M.J. 2003. The concentrations and bioconcentration factors of copper and zinc in edible mushrooms. Archives of Environmental Contamination and Toxicology, 44, 180-188. http://dx.doi.org/10.1007/s00244-002-2051-0

Alonso, J., Salgado, M.J., Garcia, M.A. \& Melgar, M.J. 2000. Accumulation of mercury in edible macrofungi: influence of some factors. Archives of Environmental Contamination and Toxicology, 38, 158-162. http://dx.doi.org/10.1007/s002449910020

Angelovičová, L. \& Fazekašová, D. 2014. Contamination of the soil and water environment by heavy metals in the former mining area of Rudňany (Slovakia). Soil and Water Research, 9(1), 18-24

Árvay, J., Bajčan, D. \& Tomáš, J. 2012. Quality of the environmental components in the alluvium of the Stiavnica river. Nitra: SUA. 221 p. ISBN 978-80-552-0817-6. (in Slovak)

Árvay, J., Demková, L., Hauptvogl, M., Michalko, M., Bajčan, D., Stanovič, R., Tomáš, J., Hrstková, M. \& Trebichalský, P. 2017. Assessment of environmental and health risks in former polymetallic ore mining and smelting area, Slovakia: Spatial distribution and accumulation of mercury in four different ecosystems. Ecotoxicology and Environmental Safety, 144, 236-244.

https://doi.org/10.1016/i.ecoenv.2017.06.020

Árvay, J., Tomáš, J., Hauptvogl, M., Kopernická, M., Kováčik, A., Bajčan, D. \& Massanyi, P. 2014. Contamination of wild-grown edible mushrooms by heavy metals in a former mercury-mining area. Journal of Environmental Science and Health part B, 49(11), 815-827. http://dx.doi.org/10.1080/03601234.2014.938550 Árvay, J., Tomáš, J., Hauptvogl, M., Massányi, P., Harangozo, L., Tóth, T. Stanovič, R., Bryndzová, Š. \& Bumbalová, M. 2015. Human exposure to heavy metals and possible public health risks via consumption of wild edible mushrooms from Slovak Paradise National Park, Slovakia. Journal of Environmental Science and Health part B, 50(11), 833-843. http://dx.doi.org/10.1080/03601234.2015.1058107

Chudzyński, K., \& Falandysz, J. 2008. Multivariete analysis of elements content of Larch Bolete (Suillus grevillei). Chemosphere 73 , 1230-1239. http://dx.doi.org/10.1016/i.chemosphere.2008.07.055

Colin-Hasen, C., Yttri, K.E., Andersen, R.A., Berthelsen, B.O. \& Steinnes, E. 2002. Mushrooms from two metal-contaminated areas in Norway: Occurrence of metals and metallothionein-like proteins. Geochemical, Exploration, Environment and Analitics, 2, 121-130.

Ducsay, L., Ložek, O., Marcek, M., Varényiová, M., Hozlár, P., Lošák, T. 2016. Possibility of selenium biofortification of winter wheat grain. Plant, Soil And environment, 62(8), 379-383. https://doi.org/10.17221/324/2016-PSE

Drewnowska, M., Hanć, A., Baralkiewicz, D. \& Falandysz, J. 2017. Pickling of chanterelle Cantharellus cibarius mushrooms highly reduce cadmium contamination. Environmental Science and Pollution Research, 24(27), 21733 21738. http://dx.doi.org/10.1007/s11356-017-9819-2

Drewnowska, M. \& Falandysz, J. 2015. Investigation on mineral composition and accumulation by popular edible mushroom common chanterelle (Cantharellus cibarius). Ecotoxicology and Environmental Safety, 113, 9-17. http://dx.doi.org/10.1016/j.ecoenv.2014.11.028

Falandysz, J. 2017. Mercury accumulation of three Lactarius mushroom species. Food Chemistry, 214, 96-101. http://dx.doi.org/10.1016/j.foodchem.2016.07.062

Falandysz, J. \& Drewnowska, M. 2017. Cooking can decrease mercury contamination of a mushroom meal: Cantharellus cibarius and Amanita fulva. Environmental Science and Pollution Research, 24(15), 13352-13357. http://dx.doi.org/10.1007/s11356-017-8933-5

Falandysz, J., Kawano, M., Świeczowski, A., Brzostowski, A. \& Dadej, M. 2003. Total mercury in wild-grown higher mushrooms and underlying soil from Wdzydze Landscape Park, northern Poland. Food Chemistry, 81, 21-26. http://dx.doi.org/10.1016/S0308-8146(02)00344-8

Falandysz, J., Kunito, T., Kubota, R., Bielawski, L., Frankowska, A. \& Falandysz, J.Jr. 2008. Multivariete characterization of elements accumulated in king bolete Boletus edulis mushroom at lowland and high mountain regions. Journal of Environmental Science and Health part A, 43, 1-8 http://dx.doi.org/10.1080/10934520802330206

Gao, X. \& Chen, C. 2012. Heavy metal pollution status in surface sediments of the coastal Bohai Bay. Water Research, 46, 1901-1911. http://dx.doi.org/10.1016/j.watres.2012.01.007

García, M.Á., Alonso, J. \& Melgar, M.J. 2009. Lead in edible mushrooms. Levels and bioaccumulation factors. Journal of Hazardous Material, 167, 777 783. http://dx.doi.org/10.1016/j.hazmat.2009.01.058

Gupta, K., Kumari, K. \& Shikha, S. 2014. Bioremediation of heavy metal polluted environment using resistant bacteria. Journal of Environmental Research and Development, 8(4), 883-889. 
Kalač, P. 2010. Trace element contents in European species of wild growing edible mushrooms: a review for the period 2000-2009. Food Chemistry, 122, 2-15.

Kalač, P. \& Svoboda, L. 2000. A review of trace element concentrations in edible mushrooms. Food Chemistry, 69, 273-281. https://doi.org/10.1016/S0308$\underline{\text { 8146(99)00264-2 }}$

Kojta, A.K., Gucia, M., Krasińska G., Saba, M., Nnorom, I.C. \& Falandysz, J. 2016. Mineral constituents of edible field Parasol (Macrolepiota procera) mushrooms and the underlying substrate from upland regions of Poland: Bioconcentration potential, intake benefits, and toxicological risk. Polish Journal $\begin{array}{llll}\text { of Environmental } & \text { Studies, 25(6), } & \text { 2445-2460. }\end{array}$ https://doi.org/10.15244/pjoes/62997

JECFA, 2011. Safety Evaluation of Certain Contaminants in Food, Prepared by the Seventy-second Meeting of the Joint FAO/WHO (2011) Expert Committee on Food Additives (JECFA) WHO Food Additives Series, vol. 959

JECFA, 2012. Safety Evaluation of Certain Food Additives, Prepared by the Seventy Fourth Meeting of the Joint FAO/WHO Expert. Committee on Food Additives (JECFA), Geneva.

Mleczek, M., Siwulski, M., Mikołajczak, P., Gąsecka, M., Sobieralski, K., Szymańczyk, M. \& Goliński, P. 2015. Content of selected elements in Boletus badius fruiting bodies growing in extremely polluted wastes. Journal of Environmental Science and Health part A, 50, 767-775. https://doi.org/10.1080/10934529.2015.1012014

Mleczek, M., Siwulski, M., Stuper-Szablewska, K., Rissmann, I., Sobieralski, K. \& Goliński, P. 2013. Accumulation of elements by edible mushroom species: Part I. Problem of trace elements toxicity in mushrooms. Journal of Environmental Science and Health part B, 48, 69-81. http://dx.doi.org/10.1080/03601234.2012.716733

Petkovšek, S.A.S. \& Pokorny, B. 2013. Lead and cadmium in mushrooms from the vicinity of two large emission sources of Slovenia. Science of the Total Environment, 443 ,

944-954

http://dx.doi.org/10.1016/j.scitotenv.2012.11.007.944-954

Rieder, S.R., Brunner, I., Horvat, M., Jacobs, A. \& Frey, B. 2011. Accumulation of mercury and methyl-mercury by mushrooms and earthworms from forest soil. Environmental Pollution, 159, 2861-2869. http://dx.doi.org/10.1016/j.envpol.2011.04.040

Rudawska, M. \& Leski, T. 2005. Trace elements in fruiting bodies of ectomycorrhizal fungi growing in Scots pine (Pinus sylvestris L.) stands in Poland. Science of the Total Environment, 339, 103-115. http://dx.doi.org/10.1016/j.scitotenv.2004.08.002

Slávik, M., Tóth, T., Árvay, J., Kopernická, M., Harangozo, L', Stanovič, R., Trebichalský, P. \& Kavalcová, P. 2014. The heavy metals content in vegetables from middle Spiš area. Journal of Microbiology, Biotechnology and Food Sciences, 3 (special issue), 277-280.

Slávik, M., Tóth, T., Harangozo, L., Árvay, J., Stanovič, R. \& Mǐ̌šík, J. 2013. The content of mercury in edible mushrooms from middle Spiš area. Journal of Microbiology, Biotechnology and Food Sciences, 2 (special issue), 2115-2124.

Stanovič, R., Árvay, J., Hauptvogl, M., Tomáś, J., Kováčik, A., Záhorcová, Z. \& Slávik, M. 2016. Determination of heavy metals concentration in raw sheep milk from mercury polluted area. Potravinárstvo - Slovak Journal of Food Science, 10(1), 95-99.

Statistical Organization of Slovak Republic. 2016. Food Consumption in the Slovak Republic in 2015, 30 pp. Available at: (www.statistics.sk).

Stefanović, V., Trifković, J., Djurdjić, S., Vukojević, V., Tešić, Ž. \& Mutić, J. 2016. Study of silver, selenium and arsenic concentration in wild edible mushroom Macrolepiota procera, health benefit and risk. Environmental Science and Pollution Research, 23(21), 22084-22098. https://doi.org/10.1007/s11356-016-7450-2

Širić, I., Humar, M., Kasap, A., Kos, I., Mioč, B. \& Pohleven, F. 2016. Heavy metal bioaccumulation by wild edible saprophytic and ectomycorrhizal mushrooms. Environmental Science and Pollution Research, 23(18), 18239-18252.

Širić, I., Kasap, A., Bedeković, D. \& Falandysz, J. 2017. Lead, cadmium and mercury contents and bioaccumulation potential of wild edible saprophytic and ectomycorrhizal mushrooms, Croatia. Journal of Environmental Science and
Health
part
$B$,
$52(3)$
$156-165$

http://dx.doi.org/10.1080/03601234.2017.1261538

Szynkowska, M.I., Pawlaczyk, A., Albinska, J. \& Paryjczak, T. 2008. Comparison of accumulation ability of toxicologically important metals in caps and stalks in chosen mushrooms. Pollish Journal of Chemistry, 82, 313-319.

Tomáš, J., Árvay, J., Tóth, T., Vollmannová, A., Kopernická, M. \& Slávik, M. 2014. The level of crop plants contamination by heavy metals from the historical mines area. Journal of Microbiology, Biotechnology and Food Science, 3 (special issue), 294-297.

Tüzen, M., Sesli, E. \& Soylak, M. 2007. Trace element levels of mushroom species from East Black Sea region of Turkey. Food Control, 18, 806-810. http://dx.doi.org/10.1016/j.foodcont.2006.04.003
Vollmann, J., Lošák, T., Pachner, M., Watanabe, D., Musilová, L., Hlušek, J. 2015. Soybean cadmium concentration: validation of a QTL affecting seed cadmium accumulation for improved food safety. Euphytica, 203(1), 177-184. https://doi.org/10.1007/s10681-014-1297-8

Ouzouni, P.K., Petridis, D., Koller, W.D., Kyriakos, A. \& Giganakos, K.A. 2009 Nutritional value and metal content of wild edible mushrooms collected from West Macedonia and Epirus. Greece. Food Chemistry, 115(4), 1575-1580. http://dx.doi.org/10.1016/j.foodchem.2009.02.014.1575-1580

Záhorcová, Z., Árvay, J., Hauptvogl, M., Tomáś, J. \& Harangozo, L. 2016. Heavy metals determination in edible wild mushrooms growing in former mining area - Slovakia: Health risk assessment. Potravinárstvo - Slovak Journal of Food Science, 10(1), 37-46. http://dx.doi.org/10.5219/528"10.5219/528

Zocher, A.L., Kraemer, D., Merschel, G. \& Bau, M. 2018. Distribution of major and trace elements in the bolete mushrooms Suillus luteus and the bioavailability of rare earth elements. Chemical Geology, 483, 491-500. https://doi.org/10.1016/j.chemgeo.2018.03.019 